\title{
A Review of Modified Steel Slag Application in Catalytic Pyrolysis, Organic Degradation, Electrocatalysis, Photocatalysis, Transesterification and Carbon Capture and Storage
}

\author{
Fu-Ping Wang, Tian-Ji Liu, Shuang Cai, Di Gao, Qing Yu, Xiao-Man Wang, Yi-Tong Wang * $\mathbb{D}$, Ya-Nan Zeng * \\ and Jun-Guo Li *
}

check for updates

Citation: Wang, F.-P.; Liu, T.-J.; Cai, S.; Gao, D.; Yu, Q.; Wang, X.-M.; Wang, Y.-T.; Zeng, Y.-N.; Li, J.-G. A Review of Modified Steel Slag Application in Catalytic Pyrolysis, Organic Degradation, Electrocatalysis, Photocatalysis, Transesterification and Carbon Capture and Storage. Appl. Sci. 2021, 11, 4539. https:// doi.org/10.3390/app11104539

Academic Editor: Francis Verpoort

Received: 24 April 2021

Accepted: 14 May 2021

Published: 16 May 2021

Publisher's Note: MDPI stays neutral with regard to jurisdictional claims in published maps and institutional affiliations.

Copyright: (c) 2021 by the authors. Licensee MDPI, Basel, Switzerland. This article is an open access article distributed under the terms and conditions of the Creative Commons Attribution (CC BY) license (https:/ / creativecommons.org/licenses/by/ $4.0 /)$.
College of Metallurgy and Energy, North China University of Science and Technology, 21 Bohai Street, Tangshan 063210, China; fwang3692@gmail.com (F.-P.W.); liutianji@ncst.edu.cn (T.-J.L.); caishuang@ncst.edu.cn (S.C.); gaodi1113@gmail.com (D.G.); qyu0688@gmail.com (Q.Y.); wxiaoman97@gmail.com (X.-M.W.)

* Correspondence: wangyt@ncst.edu.cn (Y.-T.W.); zengyanan@ncst.edu.cn (Y.-N.Z.); lijg99@163.com (J.-G.L.)

Abstract: As a by-product of the iron and steel industry, steel slag is rich in catalytically active substances and can therefore be used as a solid catalyst. Many studies have shown that the application potential of steel slag in catalysis is huge, which provides new development space for its application, thereby increasing its additional utilization value. This article primarily reviews the research progress in catalytic fields such as catalytic pyrolysis, organic degradation, electrocatalysis, photocatalysis, transesterification, and carbon capture and storage, as well as the modification methods of steel slag. The catalytic performance of the modified steel slag has been further improved, and it has the meaningful characteristics of high efficiency, cleanliness, and low costs.

Keywords: steel slag; modification; catalysis; hazardous solid waste; additional utilization value

\section{Introduction}

In 2019, the world's crude steel production was 2.196 billion tons [1]. According to the main smelting process, steel slag can be divided into basic oxygen furnace (BOF) slag (also known as converter slag) and electric furnace (EAF) slag [2]. The molten steel slag produced from the steelmaking furnace goes through different means of processing, such as hot steel slag splashing after crushing screening-magnetic separation process technology, fever steel slag treatment technology, rotary cylinder process technology [3], etc. Steel slag is a by-product of the steel industry [4]; its production is $15-20 \%$ of crude steel production and cumulative storage exceeds 1.2 billion tons in China [5]. The accumulation of a large amount of steel slag causes problems such as land occupation, environmental pollution, and the waste of resources [6]. Although the utilization of steel slag has been continuously optimized and improved in recent years, the current utilization rate of steel slag in China is only $22 \%$, which is far behind developed countries such as the United States, Japan, Germany, and France. The utilization rate of steel slag in these countries is close to 100\% [7]. Therefore, there is still a void in terms of development in the resource utilization of steel slag in China. The differences in steelmaking raw materials and smelting processes result in different chemical compositions and mineral phase types in steel slag, but most of its main chemical components are composed of calcium oxide $(\mathrm{CaO})$, magnesium oxide $(\mathrm{MgO})$, silicon oxide $\left(\mathrm{SiO}_{2}\right)$, aluminum oxide $\left(\mathrm{Al}_{2} \mathrm{O}_{3}\right)$, ferrous oxide $(\mathrm{FeO})$, ferric oxide $\left(\mathrm{Fe}_{2} \mathrm{O}_{3}\right)$, manganese oxide $(\mathrm{MnO})$, free calcium oxide ( $\left.\mathrm{f}-\mathrm{CaO}\right)$, free magnesium oxide ( $\mathrm{f}$ $\mathrm{MgO}$ ), etc. [8]. Due to the different origins and smelting processes, the percentages of chemical components are also different, but for most steel slags, $\mathrm{CaO}, \mathrm{MgO}, \mathrm{SiO}_{2}$, and $\mathrm{FeO} / \mathrm{Fe}_{2} \mathrm{O}_{3}$ account for the main part. The chemical composition of certain steel slag is shown in Table 1 [9]. The main mineral composition of steel slag is dicalcium silicate $\left(\mathrm{C}_{2} \mathrm{~S}\right)$, tricalcium silicate $\left(C_{3} S\right)$, dicalcium ferrite $\left(C_{2} F\right)$, and solid solution $(R O)$. [10]. Steel slag is 
rich in metal elements, non-metallic elements, and has good structural properties including porous, high density, high hardness, wear resistance, and high compressive strength; thus, it has potential for high value-added applications.

Table 1. Chemical composition of steel slag [9].

\begin{tabular}{ccccccccc}
\hline \multirow{2}{*}{ Type } & $\mathbf{8}$ Chemical Composition (wt\%) \\
\cline { 2 - 9 } & $\mathrm{CaO}$ & $\mathbf{M g O}$ & $\mathrm{Fe}_{\mathbf{2}} \mathbf{O}_{3} / \mathrm{FeO}$ & $\mathbf{S i O}_{\mathbf{2}}$ & $\mathbf{A l}_{\mathbf{2}} \mathbf{O}_{3}$ & $\mathbf{M n O}$ & $\mathbf{S O}_{3}$ & $\mathbf{P}_{\mathbf{2}} \mathbf{O}_{5}$ \\
\hline Steel slag & 40.65 & 10.88 & 20.57 & 10.10 & 1.70 & 0.06 & 0.24 & 1.04 \\
\hline
\end{tabular}

Currently, steel slag is mainly used in architecture, agriculture, industry, and other fields. In architecture, steel slag is often used instead of cement to improve the strength of the mixture due to containing the gel composition in steel slag [11], or used to produce steel slag bricks [12], concrete aggregates [13], and asphalt mixtures [14]. It is also used for soil improvement and in chemical fertilizers [15]. In the industrial field, steel slag is not only recycled by steel mills as a co-solvent to replace limestone, dolomite, and other raw materials [16], but also it is often used to extract metals [17]. However, the utilization rate of steel slag in China has not been improved. There may be several reasons: (i) there is a certain amount of iron particles in the steel slag, which leads to its poor grindability; (ii) the hydration activity of steel slag is low, especially the early activity because only a few highly active minerals exist in steel slag [18]; and (iii) the volume stability of steel slag is poor [19] since the high content of $\mathrm{f}-\mathrm{CaO}$ and $\mathrm{f}-\mathrm{MgO}$ leads it to undergo hydration reaction to result in volume expansion. However, steel slag used in the field of catalysis is not impacted by the above reasons, and the surplus steel slag will greatly reduce the cost of catalyst raw materials. In recent years, through the research and exploration of steel slag in catalysis, it has been found that the application of steel slag in catalysis has great potential—especially after the modification of steel slag, the catalytic performance is greatly improved. Therefore, it is feasible to use modified steel slag as a catalyst in terms of both catalytic efficiency and cost, and it also provides a new way to utilize steel slag. Similarly, studies and exploration in this area have been carried out in other countries. Lee et al. [20] used steel slag from a Korean steel plant as a catalyst to enhance the homogenous reaction kinetics of $\mathrm{CO}_{2}$ on pig manure pyrolysis. When steel slag is used as a catalyst, the reaction kinetics of $\mathrm{CO}_{2}$ to pig manure was as high as $80 \%$. Matthaiou et al. [21] used steel slag from a steel plant in northern Spain as raw material and obtained a series of iron-containing catalysts by acid modification, which were used to catalyze sodium persulfate to produce active substance to remove propylparaben, and achieved an $80 \%$ removal rate. Therefore, the study of steel slag as a catalyst is not only suitable for China, but also feasible in many countries in the world. At the same time, it provides guidance for the recycling and utilization of metallurgical solid waste in China and other countries around the world.

\section{Feasibility Analysis of Steel Slag as Catalyst}

Steel slag contains many metal species that could initiate catalysis, so it can be used as a catalyst to enhance reaction kinetics. When steel slag is treated by acid modification, high-temperature activation modification, composite modification, etc., on the one hand, the content of catalytically active substances in the modified steel slag increases to improve its catalytic performance; on the other hand, the specific surface area of the steel slag increases, which leads the catalytic active sites to increase to improve catalytic performance. It also exhibits highly developed mesoporosity, which is necessary to promote the entry of reactants into the internal catalytic surface [22]. Therefore, as a kind of solid waste, steel slag has great catalytic advantages because of its large reserves, strong plasticity, high efficiency, low cost, and good availability. It had great potential for application in catalysis. 


\section{Modification Method of Steel Slag}

\subsection{Acid Modification}

Steel slag contains many alkaline oxides. When in contact with the acid solution, chemical reactions occur, and soluble salts enter the solution, which changes its structure, increases its specific surface area and pore size, enlarges the contact surface between the steel slag and the reactant, and improves the catalytic performance. However, we should pay attention to the acid concentration during the modification process-too strong an acid solution may lead to a fragile and unstable surface structure of steel slag [23]. Commonly used acid modifiers are hydrochloric acid, sulfuric acid, and some weak acids, such as formic acid and oxalic acid [24-26].

\subsection{Alkali Modification}

Most of the substances in steel slag are metallic oxides, in which the content of $\mathrm{CaO}$ is about 20-30\%, and a large amount of $\mathrm{CaO}$ inhibits the nucleation of the crystal phase [27]. When an alkali modifier is added, $\mathrm{Ca}(\mathrm{OH})_{2}$ insoluble or slightly soluble substances are generated. Due to a large amount of $\mathrm{CaO}$ removal, the specific surface area, the pore size of the steel slag, the percentage of other effective catalytic substances, and the catalytic active sites increase [22]. Therefore, the catalytic performance of alkali-modified steel slag in some catalytic applications is better than that of acid modification. Similarly, too high alkaline solution concentration will destroy the pore structure of steel slag, so it is necessary to pay attention to alkali concentration during the modification process [23]. Commonly used alkali modifiers include $\mathrm{NaOH}$ and others [28,29].

\subsection{High Temperature Activation Modification}

High temperature activation modification is a method of heating steel slag under a certain high temperature condition. Normally, an endothermic reaction occurs during high-temperature treatment. High temperature is conducive to the decomposition of active components, thereby generating more fine and catalytically active transition metal oxide grains [30], resulting in the crystal structure of slag changing and the surface of steel slag being destroyed. The smoothness is destroyed, the surface becomes rough and shows various irregular grooves and large loose structures, which is more conducive to the contact between the reactant and the steel slag, thereby improving the catalytic activity of the steel slag.

\subsection{Compound Modification}

Composite modification is a method in which one or several materials are mixed with steel slag in a certain proportion and then subjected to high-temperature calcination or other modification treatments. The method, commonly used in the production of composite modified electrodes slag particles, produces organic material for an electrical solution with higher catalytic performance and low-cost characteristics [31,32].

\subsection{Physical Modification}

The physical modification of steel slag mainly refers to the method of mechanical activation to grind steel slag to reduce its the average particle size. Grinding steel slag produces lattice distortion and local damage, along with various defects, which increase its specific surface area and result in catalytic active sites increasing to improve reaction activity. Due to the poor grindability of steel slag [33], two factors (cost and particle size) must be considered when grinding. Thus, physical modification method is usually used as the first step in steel slag modification.

\section{Modified Steel Slag as Catalysts}

\subsection{Catalytic Pyrolysis}

In the process of catalytic pyrolysis, the practical application of bio-oil is limited due to its disadvantages such as high oxygen content, low calorific value, high acidity, high 
thermal instability, and so on [34]. In order to make the properties of bio-oil closer to fossil fuel to a greater extent, it is necessary to improve the quality of bio-oil. Catalytic cracking is considered to be a more effective method [35], so it is very important to find a suitable catalyst. Metal oxides and non-metal oxides are also commonly used in the catalytic upgrading of bio-oil. For example, Lin et al. [36] carried out catalytic pyrolysis experiments on wood-polypropylene composites using oxides such as $\mathrm{CaO}, \mathrm{Fe}_{2} \mathrm{O}_{3}$, and $\mathrm{MgO}$. $\mathrm{CaO}$, due to its strong alkalinity, can effectively remove the oxygen content in the produced oil. At the same time, it can reduce the acid compounds in the pyrolysis products and increased the content of cyclopentanone and olefin. It was reported in [37] that the catalytic performance of $\mathrm{Fe}_{2} \mathrm{O}_{3}$ and $\mathrm{MgO}$ is weaker than that of $\mathrm{CaO}$, but $\mathrm{MgO}$ has strong chainbreaking activity, and the increase in olefin is obvious. $\mathrm{Fe}_{2} \mathrm{O}_{3}$ can promote the generation of aromatic hydrocarbons. In short, these three oxides can reduce the oxygen content of bio-oil and improve its quality. Oxides such as $\mathrm{Al}_{2} \mathrm{O}_{3}, \mathrm{CaO}, \mathrm{MgO}, \mathrm{CuO}$, and $\mathrm{Fe}_{2} \mathrm{O}_{3}$ were selected for catalytic pyrolysis experiments in [38]. Due to more decarboxylation or less dehydration, $\mathrm{CaO}$ and $\mathrm{Al}_{2} \mathrm{O}_{3}$ have the best performance when considering the yield and deoxygenation of bio-oil comprehensively. When considering the mass, water content, and $\mathrm{pH}$ value of bio-oil, $\mathrm{CaO}$ shows the best performance in the balance of the three conditions. The oxygen in bio-oil is mainly removed by $\mathrm{CO}$ and $\mathrm{CO}_{2}$ through the reaction with oxides, so the amount of gas in catalytic pyrolysis is increased, and these bio-syngases can also be used as gas fuel. Therefore, through the catalysis of these oxides, not only can the quality of bio-oil be improved, but also the gas fuel content can be increased. It can be seen from Table 1 that the main components of steel slag contain these oxides. As long as we remove the active components through some simple modification methods and increase the contact between the pyrolysis products and the active components, the steel slag can show good catalytic performance to the maximum extent. The following will introduce some research achievements in the catalytic pyrolysis of modified steel slag in recent years.

Guo et al. [39] used modified steel slag as a catalyst to improve gas production efficiency and the conversion rate of tar when studying the properties of pyrolysis and tar cracking and reforming of materials. For the research, after the steel slag calcined at 900 ${ }^{\circ} \mathrm{C}$, relatively stable $\mathrm{Fe}_{2} \mathrm{O}_{3}$ and $\mathrm{MgFe}_{2} \mathrm{O}_{4}$ crystals formed on the surface of the steel slag to produce a loose porous structure, which was conducive to the contact between the active components in the steel slag and the reactants to improve the catalytic activity of the steel slag. The reduced gas generated in the process of biomass pyrolysis reduced the $\mathrm{Fe}_{2} \mathrm{O}_{3}$ in the steel slag to low-valent iron. When the catalytic performance of the steel slag was further improved, the conversion rate of tar and the efficiency of synthesis gas increased accordingly with the maximum conversion rate of $94.1 \%$ for tar obtained. Steel slag was effective in long-term applications as a catalyst in the removal of biomass tar. This not only recycled the steel slag, but also improved the efficiency of biomass pyrolysis and tar cracking and reforming, and avoided secondary pollution caused by the production of tar in the process of biomass pyrolysis.

Guo et al. [40] added a small amount of nickel (0-10 wt\%) in the slag, then calcined it at $900{ }^{\circ} \mathrm{C}$ to prepare nickel-modified steel slag to catalyze pine sawdust native biomass pyrolysis tar; the specific modification process is shown in Figure 1. The calcined steel slag was mainly composed of $\mathrm{Fe}_{2} \mathrm{O}_{3}$ and $\mathrm{MgFe}_{2} \mathrm{O}_{4}$. Granular $\mathrm{NiO}$ particles formed on the surface of the nickel-modified steel slag and were highly dispersed, resulting in a porous structure of the catalyst. Studies showed that the modified steel slag exhibited good activity in converting biomass primary tar into synthesis gas (mainly include $\mathrm{CO}, \mathrm{H}_{2}, \mathrm{CH}_{4}$, etc.). Within a certain loading range, with the increasing of the loading of nickel, the synthesis gas yield increased significantly. The reduced gas in the synthesis gas, in turn, reduced the iron and nickel oxides in the steel slag into low-valent iron and nickel, and new active centers were formed by the low-valent iron and nickel. Additionally, the surface of the nickel-supported steel slag owned the stable porous structure, which enabled the steel slag-supported catalyst to be repeatedly used in the reforming process of biomass tar. 


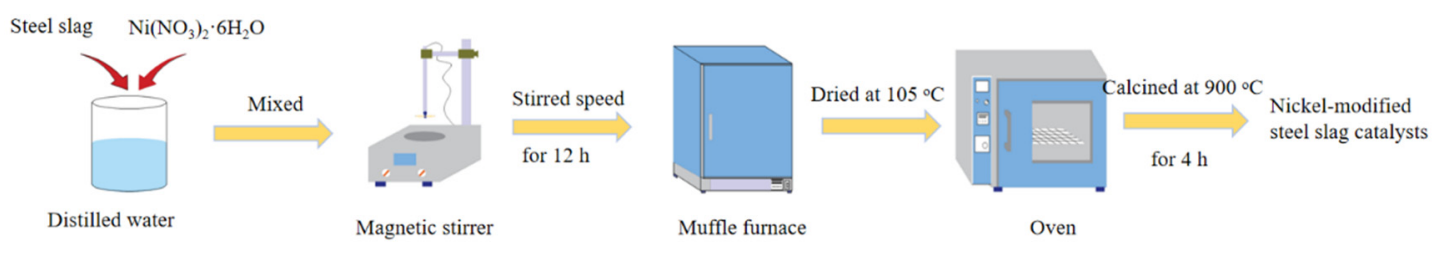

Figure 1. Nickel-modified steel slag catalysts to catalyze pine sawdust native biomass pyrolysis tar.

Kabir et al. [41] used steel slag-derived zeolite (FAU-SL) to catalyze the pyrolysis of oil palm mesocarp fiber (OPMF). They used electric arc furnace slag (EAFS) as the precursor for the synthesis of the target catalyst. EAFS after grinding, sieving, and $\mathrm{H}_{2} \mathrm{SO}_{4}$ solution mixture was stirred separately, then through the heating and cooling the referred FAU-SL zeolite catalyst was obtained. The modification flowchart is shown in the Figure 2. Studies showed that the bio-oil yield of OPMF catalytic pyrolysis reached the highest $47 \mathrm{wt} \%$ at $550{ }^{\circ} \mathrm{C}$. At the same time, the addition of the catalyst changed the organic composition of bio-oil, the relative content of oxygen-containing organics decreased, and the aromatic organics increased, which improved the quality of bio-oil. Compared with other common zeolites, the FAU-SL catalyst had higher efficiency and better catalytic performance.

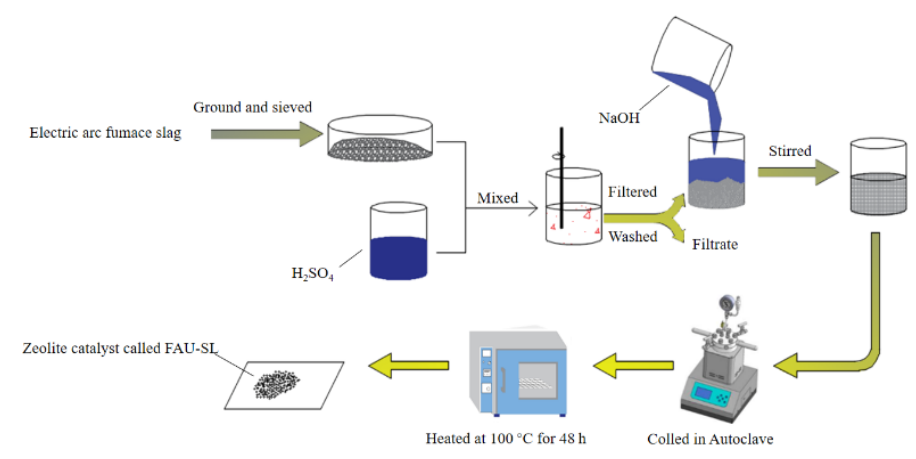

Figure 2. FAU-SL catalyst modification for pyrolysis of peel fiber.

\subsection{Organic Matter Degradation}

Studies have shown that the presence of the element Fe in steel slag can produce Fenton or Fenton-like reactions in the degradation process of organic matter, thus improving the degradation of organic matter [42]; moreover, the presence of iron made the steel slag particles present magnetic properties [43], and thus it had a good recycling performance.

Cheng et al. [44] studied the modified slag as a Fenton-like catalyst to treat alachlor wastewater. Due to the dissolution of calcium minerals in the steel slag, the $\mathrm{pH}$ of the solution rapidly increased to about 10, and the Fenton-like reactions had low reaction efficiency under high $\mathrm{pH}$ conditions [45]. To eliminate this effect, they modified the steel converter slag (SCS) with salicylic acid-methanol (SAM); the specific process of modification is shown in Figure 3. The results show that iron oxides in steel slag can be dissociated into $\mathrm{Fe}^{2+}$ after SAM treatment. $\mathrm{Fe}^{2+}$ and $\mathrm{H}_{2} \mathrm{O}_{2}$ react to generate hydroxyl radical $(\cdot \mathrm{OH})$, and then oxidize and degrade organic pollutants. Secondly, after steel slag is treated with acid, a large number of calcium minerals can be removed to prevent the steel slag from dissolving alkaline substances in the catalytic process, which increases the $\mathrm{pH}$ and leads to the precipitation of $\mathrm{Fe}^{2+}$. SAM solution could selectively remove calcium silicate minerals on the surface of steel slag, and according to the degradation experiment data, it can be concluded the catalytic ability of the modified steel slag in the Fenton-like reaction is higher than that of the unmodified steel slag. Further research showed that the prepared SAM modified steel slag catalyst had high recyclability and can be reused four times without significant loss of activity. The steel slag modified by the SAM Fenton-like reaction system had the characteristics of low cost and high catalytic performance, and may be an important technology for large-scale practical application. 


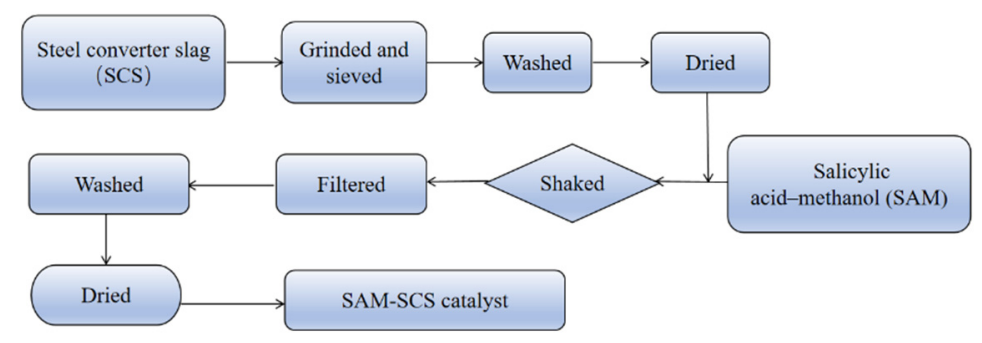

Figure 3. SAM-SCS catalyst modification.

Cheng et al. prepared a new type of catalyst through acid modification treatment of steel slag, and studied its degradation rate of sulfamethazine (SMZ) in a Fenton-like system [26]. In this study, a new type of $\mathrm{Fe} / \mathrm{Co}$ composite catalyst was synthesized through the modification of SCS by SAM and cobalt nitrate $\mathrm{Co}\left(\mathrm{NO}_{3}\right)_{2}$. The modification flowchart is shown in Figure 4. Given the above discussion, it is known that through acid modification, steel slag's catalytic efficiency has been greatly improved. After the addition of $\mathrm{Co}^{2+}$, $\mathrm{Co}^{2+}$ can also carry out Fenton-like reactions under neutral conditions, which can further break through the constraining conditions of $\mathrm{pH}$. The results showed that with a Co-SAM$\mathrm{SCS} / \mathrm{H}_{2} \mathrm{O}_{2}$ Fenton-like system with a wide $\mathrm{pH}$ range, the SMZ degradation was very effective. In the initial $\mathrm{pH}$ value of 7 , the SMZ degradation rate in the Co-SAM-SCS $/ \mathrm{H}_{2} \mathrm{O}_{2}$ system was 16.21 times that of the unmodified $\mathrm{SCS} / \mathrm{H}_{2} \mathrm{O}_{2}$ system in the $\mathrm{SMZ}$ degradation rate. The high surface area and synergy of Co-SAM-SCS from Co and Fe introduced in the sample contribute to good stability and reusability of catalyst. Additionally, Co-SAM-SCS had low iron and cobalt leaching. All of this showed that this modified method was effective and reasonable.

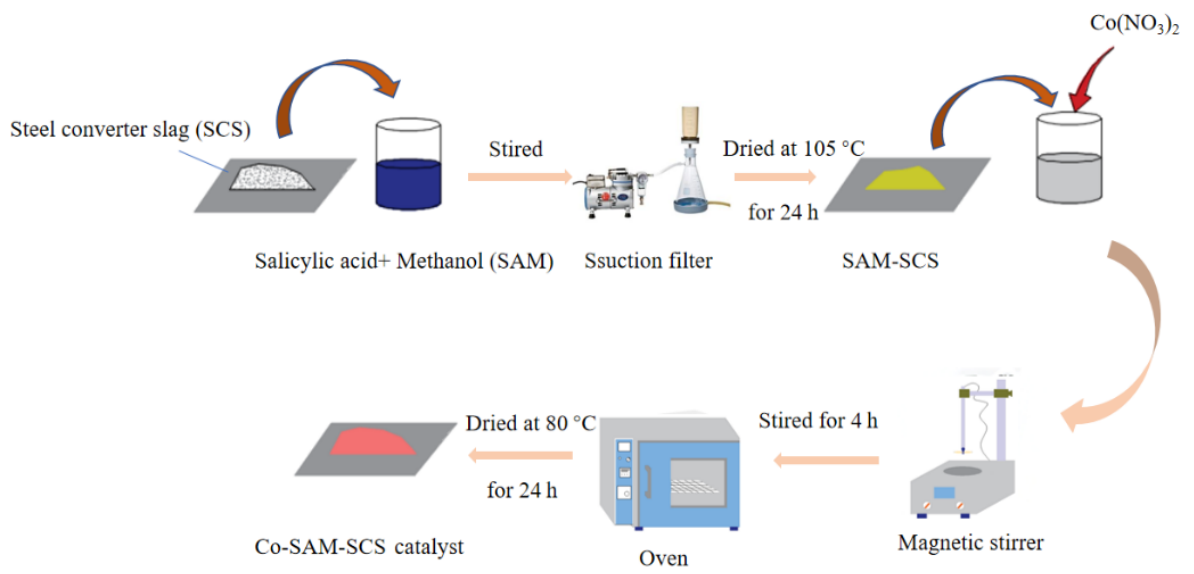

Figure 4. Co-SAM-SCS catalyst modification for SMZ degradation.

Yoon et al. [46] prepared a new catalyst with magnetically separable steel slag (MSS) as a carrier on the premise that there were magnetic substances in steel slag that can remove para-nitrophenol (p-Np) in wastewater. MSS was prepared by the grinding, separation, impregnation, and calcination of steel slag. After five magnetic separations of MSS, a $\mathrm{Cu}$ loaded catalyst $\mathrm{Cu} @$ MSS was prepared by wet impregnation method. The soluble calcium oxide on the surface of MSS reacts with water to form precipitate through magnetic separation, which continuously accumulates and removes calcium hydroxide (which is a known catalytic P-NP reduction inhibitor) [47]. The loaded $\mathrm{Cu}$ particles are changed into reducing $\mathrm{Cu}(0)$ in $\mathrm{NaBH}_{4}$ solution, and then $\mathrm{p}-\mathrm{NP}$ is reduced. However, $\mathrm{Fe}(0)$ and $\mathrm{Fe}(\mathrm{II})$ in steel slag can transfer electrons to $\mathrm{Cu}$ particles, thus enhancing the activation of $\mathrm{Cu}$ particles. The Fe content of the modified steel slag significantly increased, and the content of $\mathrm{Ca}$ (catalytic inhibitor) relatively reduced. Studies showed that $\mathrm{Fe}$ and supported $\mathrm{Cu}$ particles play a role in assisting each other in catalysis; the removal power of $\mathrm{p}-\mathrm{Np}$ was enhanced, 
so it had good catalytic performance. Through repeated recycling experiments, it can be known that the Cu@MSS catalyst had good reusability and good stability, which showed that MSS had good potential as a support material for the synthesis of new metal catalysts and can be applied in the field of environmental governance and wastewater treatment.

\subsection{Electrocatalysis}

Electrochemical oxidation is an important advanced oxidation technology (AOT) that had been successfully used in many fields [48], but conventional AOTs were not very efficient. Therefore, it was necessary to find more suitable electrode materials and new technical means. Steel slag contains a variety of metal oxides and non-metal oxides, such as $\mathrm{CaO}, \mathrm{Fe}_{2} \mathrm{O}_{3}, \mathrm{Al}_{2} \mathrm{O}_{3}$, and $\mathrm{SiO}_{2}$ [49]. Considering the composition and characteristics of steel slag, it was feasible and cost-effective to prepare particle electrodes from steel slag. Combined with the three-dimensional electrode oxidation reactor, some studies in recent years found that this was feasible and had good application prospects. The reaction mechanism of electrocatalysis is as follows: when the electrode is energized, $\mathrm{H}_{2} \mathrm{O}_{2}$ will be generated, and the active component in the catalyst reacts with $\mathrm{H}_{2} \mathrm{O}_{2}$ to produce $\cdot \mathrm{OH}$, which then degrades the pollutants [50].

Wang et al. [43] ground the clean steel slag into powder, mixed it with clay and a poreforming agent, and then rolled the mixture into particles with a diameter of $3-5 \mathrm{~mm}$. The particles were heated in a tube furnace at $1050{ }^{\circ} \mathrm{C}$ to obtain a particle electrode, as shown in Figure 5, which was used in the research of advanced treatment of oil field wastewater. Studies showed that the electrochemical reactor with magnetic steel slag particles as the particle electrode can remove more than $85 \%$ of the total organic carbon within $2 \mathrm{~h}$, which was considered to be effective, and had high reusability and better performance in practical applications. Wang et al. [51] prepared a steel slag particle electrode after heating mixed particles of steel slag in a tube furnace at $1050{ }^{\circ} \mathrm{C}$ for $30 \mathrm{~min}$, and studied the use of modified steel slag particle electrodes for electrocatalytic degradation of rhodamine $B$ $(\mathrm{RhB})$. In the catalytic process, $\mathrm{Fe}^{2+}$ played a major role in the steel slag electrodes. $\mathrm{Fe}^{2+}$ and $\mathrm{H}_{2} \mathrm{O}_{2}$ oxidize to produce the active substance $\cdot \mathrm{OH}$, and then degrade $\mathrm{RhB}$. In the process of degradation, air can be passed to ensure the content of $\mathrm{H}_{2} \mathrm{O}_{2}$. These new particle electrodes showed excellent catalytic activity in the degradation of RHB compared with ceramic particles of other electrode materials. Within $60 \mathrm{~min}$, the degradation rate of RHB reached an astonishing $82.4 \%$ under ventilation and $65.45 \%$ without air. The electrode particles exhibited a very satisfactory cycle performance.

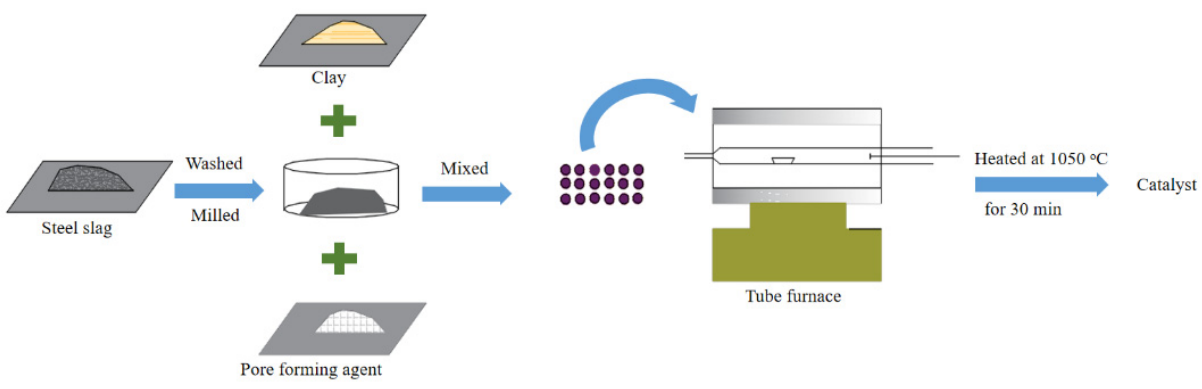

Figure 5. Steel slag particle electrode catalyst modification process.

The materials commonly used to prepare particle electrodes are activated carbon particles, ceramic filter materials, and zeolite [52]. The specific surface area and pore structure of zeolite enabled it to absorb electrolytes and electrochemical reaction species [53]. However, the conductivity of zeolite is poor, leading to high energy consumption, which hindered the application of electrochemical systems [54]. Zeolite had a certain degree of adhesion [55]; therefore, a mixture of steel slag and zeolite can prepare a particle electrode with excellent performance, good electrical conductivity, and low cost. Zhang et al. [32] used a particle electrode made of modified steel slag in a three-dimensional 
electrocatalytic system for $\mathrm{RhB}$ degradation. They mixed steel slag powder, zeolite powder, and $\mathrm{Sn} / \mathrm{Mn}$ of the active ingredient in a certain proportion into a spherical shape, and sintered it in a muffle furnace at $1190{ }^{\circ} \mathrm{C}$ to obtain Sn/Mn loaded zeolite particles steel slag electrodes. The modification flowchart is shown in Figure 6. With the addition of $\mathrm{ZnO}$ and $\mathrm{MnO}_{2}$, the catalytic activity of the particle electrode significantly improved, and stronger and more active substances such as $\cdot \mathrm{OH}, \cdot \mathrm{O}^{2-}, \cdot \mathrm{O}^{-}$and $\cdot \mathrm{HO}^{2-}$ could be produced. At the same time, the electrode particles have more active sites and reaction space for the degradation of RhB by active substances. Catalytic performance will be greatly improved. The modification flowchart is shown in Figure 6. Results showed that the degradation rate in the catalytic system reached $95.0 \%$. It showed that the catalytic performance of the $\mathrm{Sn} / \mathrm{Mn}$-supported steel slag zeolite particle electrode was relatively efficient, and the preparation of the electrode was simple and cheap. Steel slag had great application potential in electrocatalytic systems, and provided an opportunity for the using of solid waste to treat refractory organic matter.

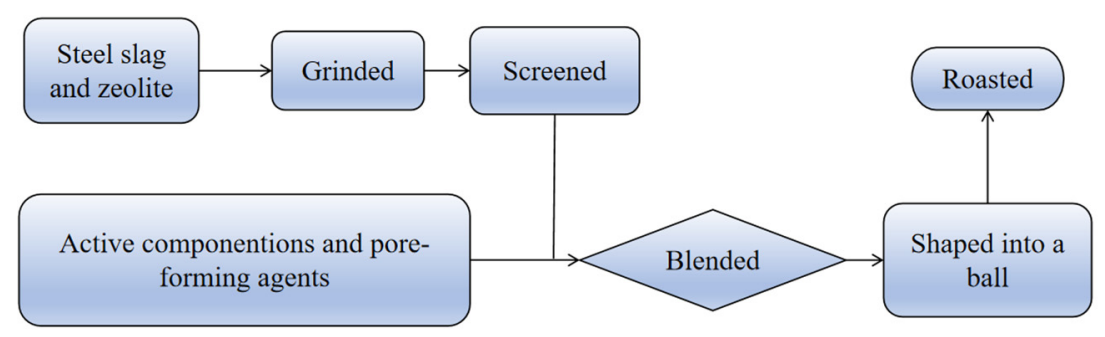

Figure 6. Preparation method of Sn/Mn loaded steel slag zeolite particle electrode.

Kaolin had the advantages of a large surface area, high mechanical strength, and low costs. It can improve the stability of the catalytic oxidation reaction. Combined with the high catalytic performance of steel slag, a kaolin/steel slag particle electrode can be developed. Wang et al. [31] used kaolin and steel slag as raw materials, calcined to prepare kaolin/steel slag particle electrodes (KSPEs), and the prepared particle electrode was degraded in a three-dimensional electrolytic cell for wastewater containing norfloxacin (NOR). First, raw materials and $\mathrm{NaHCO}_{3}$ were mixed in a certain proportion to form spherical particles with a diameter of 1-3 $\mathrm{mm}$, and then calcined in a muffle furnace at high temperature for a period of time to obtain KSPEs. The modification process is shown in Figure 7. KSPEs are polarized by electrostatic induction to form microelectrodes. KSPEs and $\mathrm{Fe}^{2+}$ react with oxygen to produce hydrogen peroxide (Equation (1)) at the cathode production $\cdot \mathrm{OH}$ (Equation (2)). NOR, under the attack of $\cdot \mathrm{OH}$, were degraded as intermediates, and KSPEs eventually degraded small molecules, such as carbon dioxide and water (Equation (3)). $\mathrm{Fe}^{3+}$ by microelectrode and cathode electron transfer of $\mathrm{Fe}^{2+}$ (Equation (4)) repeated degradation. The results show that when the voltage is $4 \mathrm{~V}$, the initial $\mathrm{pH}$ value is 3.0, and the initial NOR concentration is $20 \mathrm{mg} / \mathrm{L}$, the degradation rate of NOR by KSPEs can reach $96.02 \%$ within $30 \mathrm{~min}$, and the removal rate of total organic matter (COD) in wastewater can reach $93.45 \%$. In addition, the yield of $\cdot \mathrm{OH}$ of KSPEs was much higher than that of the blank kaolin particle electrode. After 10 degradation cycle tests, the degradation rate of NOR decreased by $8.76 \%$, and the removal rate of COD decreased by $18.52 \%$. Therefore, it can be seen that KSPEs have high catalytic activity and stability, indicating that KSPEs have great potential in the electrochemical treatment of wastewater.

$$
\begin{gathered}
\mathrm{O}_{2}+2 \mathrm{H}^{+}+2 \mathrm{e}^{-} \rightarrow \mathrm{H}_{2} \mathrm{O}_{2} \\
\mathrm{Fe}^{2+}+\mathrm{H}_{2} \mathrm{O}_{2} \rightarrow \mathrm{Fe}^{3+}+\cdot \mathrm{OH}+\mathrm{OH}^{-} \\
\mathrm{NOR}+\cdot \mathrm{OH} \rightarrow \text { Intermediates }+\mathrm{CO}_{2}+\mathrm{H}_{2} \mathrm{O} \\
\mathrm{Fe}^{3+}+\mathrm{e}^{-} \rightarrow \mathrm{Fe}^{2+}
\end{gathered}
$$




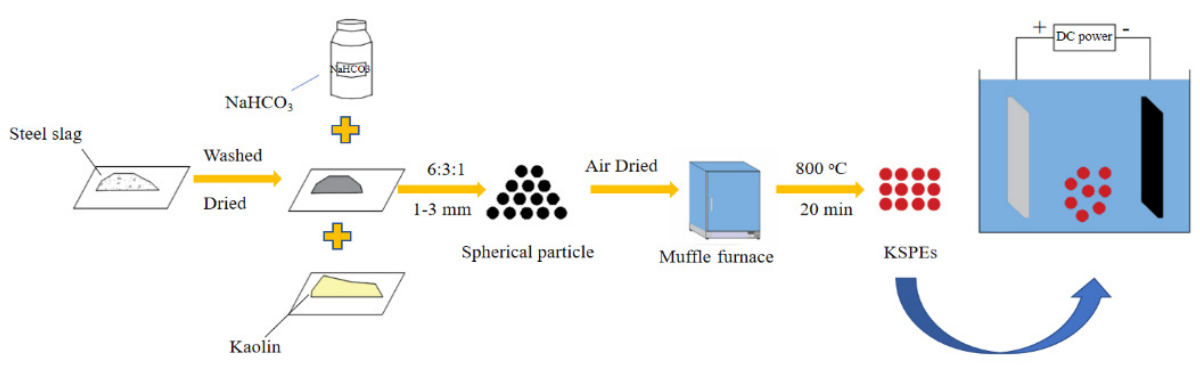

Figure 7. KPEs catalyst production for catalytic degradation of NOR.

\subsection{Photocalysis}

Sarkar et al. [24] modified the steel slag with hydrochloric acid, dimethylformamide solvent, p-phthalic acid, and methylene blue (MB) to prepare MIL-53(Fe) $/ \mathrm{SiO}_{2}$ photocatalyst; the modification process is shown in Figure 8. Using photodegradation experiment of $\mathrm{MB}$ to evaluate its photocatalytic efficiency, the results showed that the prepared MIL$53(\mathrm{Fe}) / \mathrm{SiO}_{2}$ photocatalyst had more photoexcited electrons $\left(\mathrm{e}^{-}\right)$and holes $\left(\mathrm{H}^{+}\right)$under $\mathrm{UV}$ irradiation, and these electron holes can generate oxygen-free radicals and hydroxyl-free radicals, and then degrade MB. Moreover, the electron hole pair generated by the steel slag modified catalyst has a long life. Studies have shown that the long life of the electron hole pair [56] also contributes to the improvement of degradation efficiency. Moreover, the modified steel slag had large photocatalytic active sites on the photoluminescent surface. Under ultraviolet light, the maximum photodegradation of methylene blue reached $66.3 \%$, which was higher than other similar photocatalysts. Chen et al. [57] used steel slag as a carrier and industrial titanium liquid as a raw material, and used a sol-gel method followed by calcination at $500{ }^{\circ} \mathrm{C}$ to prepare a $\mathrm{TiO}_{2}$ photocatalyst supported on steel slag, and studied its catalytic degradation performance for phenol. The results showed that the photocatalytic performance of the catalyst was better under the irradiation of ultraviolet light, and with the increased dosage of catalyst, the number of photogenerated electrons and photogenerated hole pairs generated by ultraviolet light will also increase, thus improving the photocatalytic reaction efficiency. The degradation of phenol was up to $78.3 \%$ when $10 \mathrm{~g} / \mathrm{L}$ of catalyst was added into $100 \mathrm{~mL}$ of phenol $(40 \mathrm{mg} / \mathrm{L})$. When the number of loading times is three, the photocatalytic degradation rate of phenol can reach $86.7 \%$, which indicates that the proper increase inthe loading times can help to improve the light catalytic properties of the modified steel slag.

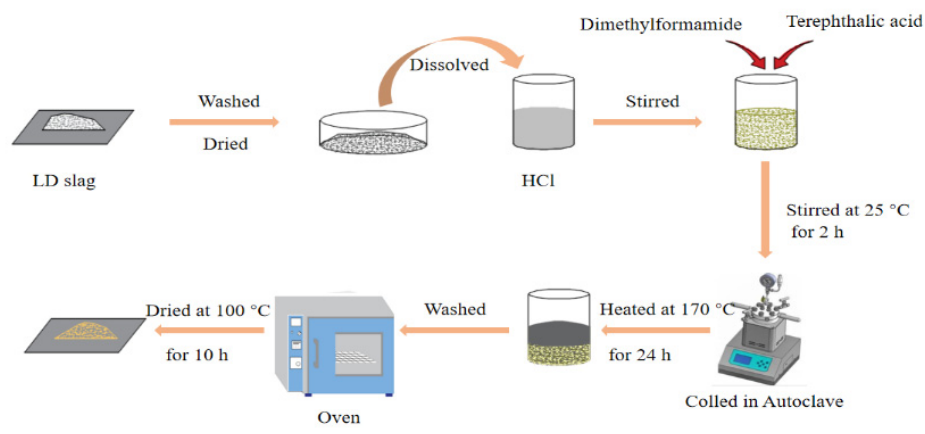

Figure 8. Preparation of MIL-53(Fe) $/ \mathrm{SiO}_{2}$ photocatalyst for photodegradation of MB.

After the steel slag was treated with aqueous solution containing alkaline, Zhang et al. [29] synthesized a novel nickel and calcium cementitious materials-based catalyst with a two-step reaction of polymerization and ion exchange, then the catalyst for the photocatalytic degradation of MB dye. The modification process is shown in Figure 9. Results showed that under ultraviolet light, the degradation rate of MB can reach $94.39 \%$ by using nickel and calcium cementitious material-based catalysts, which was much higher than that without catalysts. In the photocatalytic oxidative degradation process, $\mathrm{Ni}^{2+}$ and iron oxide 
played an important role in the catalytic process. Among them, $\mathrm{Ni}^{2+}$ contributed to the generation of photo-generated electrons, while iron oxides contributed to the generation of the catalytic potential of electrons, both of which increased the photocatalytic efficiency. Shao et al. [58] used alkali modification to convert steel slag into steel slag-derived calcium silicate hydrate (CSH), used CSH to adsorb heavy metals, and then carried out photocatalytic degradation experiments on organic pollutants. Studies showed that this kind of CSH modified by steel slag showed good adsorption performance for heavy metals and good catalytic performance for the degradation of organic pollutants. Under low-power visible light conditions, the MB removal rate with this modified photocatalyst can reach $63 \%$ in $8 \mathrm{~h}$. Using steel slag-derived CSH to adsorb heavy metals and photocatalysts in wastewater not only met the requirements of high performance, but also met the requirements of low cost. This research had important significance for the resource utilization of steel slag and provided a reference for seeking more reasonable and efficient steel slag utilization methods, and at the same time, provided a reliable method for the treatment of heavy metal and organic pollutants in wastewater.

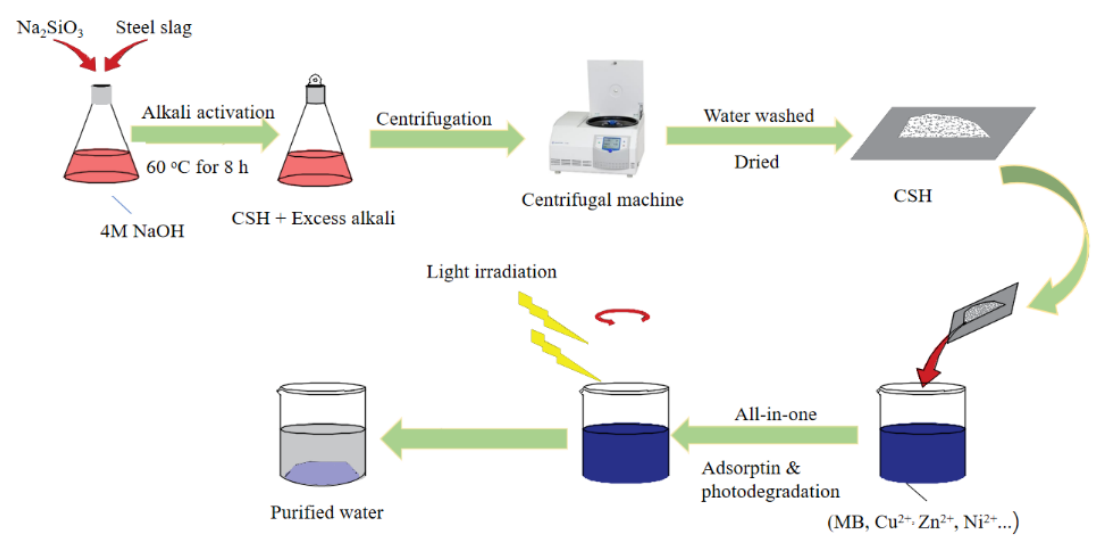

Figure 9. Nickel and calcium cementitious materials-based catalyst for the MB dye photocatalytic degradation experiments.

\subsection{Transesterification}

Renewable energy has been one of the hot topics in the field of energy research. Among renewable energy sources, biodiesel has attracted much attention from researchers due to its similar properties to petroleum diesel: non-toxic and harmless, higher flash point, higher lubricity, and renewable advantages [59]. Biodiesel is catalyzed by the transesterification of triglyceride and methanol, so the preparation of highly efficient, recyclable, and low-cost catalysts plays an important role in the yield of biodiesel [60]. So far, a variety of solid catalysts have been developed for transesterification reactions, such as $\mathrm{Ca} / \mathrm{Al} / \mathrm{Fe}_{3} \mathrm{O}_{4}$, $\mathrm{Fe}_{2} \mathrm{O}_{3} / \mathrm{CaO}$, and basic zeolite [61-63]. Zhu et al. [64] prepared a heterogeneous $\mathrm{CaO} / \mathrm{Ag}$ nano-catalyst and applied it to the transesterification of soybean oil to prepare biodiesel. The yield of biodiesel was optimized by response surface methodology (RSM), and the final yield of biodiesel could reach over $90 \%$. Under the same reaction conditions, the yield of biodiesel catalyzed by $\mathrm{CaO}$ can also reach more than $85 \%$, and all of them have good cycling performance. Li et al. [65] prepared a novel magnetic mesoporous polyphase basic catalyst (Fe@C-Sr) for the transesterification reaction to produce biodiesel. The catalyst has the characteristics of rich source, easy separation, environmentally friendly, and high catalytic efficiency, and its conversion rate is still $91.93 \%$ after four cycles. Xie et al. [66] prepared a magnetic $\mathrm{Fe}_{2} \mathrm{O}_{3} / \mathrm{SiO}_{2}$ composite catalyst for the simultaneous transesterification and esterification of low-cost oil into biodiesel. Under suitable reaction conditions, a 93.3\% oil conversion rate and complete conversion rate of free fatty acids can be achieved, and the catalyst can be reused many times without obvious catalytic activity. Through the summary and analysis of the above studies, we can see that when preparing catalytic biodiesel catalysts, cost, efficiency, recyclability, and the impact on the environment should 
be considered at the same time, and steel slag contains $\mathrm{Fe}_{2} \mathrm{O}_{3}, \mathrm{Fe}_{3} \mathrm{O}_{4}, \mathrm{CaO}$, and $\mathrm{SiO}_{2}$ and other active oxides. First of all, the application potential of steel slag in this field can be analyzed from its composition. Steel slag, as a kind of rich metallurgical solid waste, will greatly reduce the cost and pollution of solid waste when it is used as a catalyst for the esterification of biodiesel. Therefore, steel slag has great potential in this field.

As a by-product of biodiesel [67], glycerol carbonate (GC) produced through transesterification reaction has high utilization value, such as a cement composite aggregate, lithium-ion battery carrier, and fuel additive [68]. Catalysts play a very important role in the conversion of glycerol. Nowadays, the main catalysts commonly used for transesterification are double-layer hydrotalcite based on calcium oxide, magnesium oxide, $\mathrm{Ca}$ or $\mathrm{Mg}$, and alkaline alumina materials [69-71]. These catalysts have high catalytic performance for GC yield. Therefore, the advantages of steel slag containing many metal oxides and for a low cost can be taken advantage of, and it is considered to be a kind of transesterification catalytic material with broad prospects.

Liu et al. [72] used modified steel slag to catalyze the transesterification reaction of dimethyl carbonate (DMC) and glycerol to synthesize glycerol carbonate (GC). They processed the steel slag through acid modification, co-precipitation, high-temperature calcination, and alkali modification to obtain the S-CaMgAlMO catalyst. The highly basic $\mathrm{O}^{2-}$ and $\mathrm{Ca}-\mathrm{O}$ in the metal oxides of $\mathrm{S}-\mathrm{CaMgAlMO}$ catalyst split hydrogen and oxygen on the glycerol molecule, then react with DMC to form the target product GC, and finally separate from the metal part of the catalyst. Therefore, the catalytic activity and the number of recyclable uses of catalysts are important reference indices. Modified steel slag enhanced the anti-leaching ability of the active center, making it reusable and stable. Secondly, the $\mathrm{S}-\mathrm{CaMgAlMO}$ catalyst showed good catalytic performance. Under the conditions of $3 \mathrm{wt} \%$ catalyst, DMC and glycerin molar ratio of $1: 3$, reaction temperature of $75^{\circ} \mathrm{C}$, and reaction time of $90 \mathrm{~min}$, the conversion rate of glycerol was $98.3 \%$ and the GC yield was as high as $96.2 \%$. After several cycles, the conversion rate of glycerol and the yield of GC can still reach $>90 \%$. S-CaMgAlMO also had the advantages of mild reaction conditions and low production costs, and showed great potential in the transesterification reaction. Okoye et al. [28] also used the modified steel slag catalyst of the ladle furnace (LF) for the transesterification reaction. They prepared the $\mathrm{NaOH}-\mathrm{LF}$ catalyst by alkali modification and high temperature calcination of steel slag. During the calcination process, $\mathrm{Na}^{+}$can uniformly diffuse into the calcium oxide structure to form $\mathrm{NaO}$, thus increasing the basicity of steel slag. Experimental research showed that, compared with unmodified steel slag catalyst, the catalytic performance of $\mathrm{NaOH}-\mathrm{LF}$ catalyst was enhanced, and weak active sites became stronger with good reusability and stability. Under the best conditions, a glycerol conversion rate of $99 \%$ and a GC yield of $96.59 \%$ were achieved.

In addition to catalyzing GC with dimethyl carbonate, glycerol can also produce hydrogen under other catalytic conditions. Osman et al. [73] used titanium oxide doped alumina extracted from aluminum foil waste as a catalyst to perform photocatalytic reactions on glycerol under the condition of light. Under the optimal conditions, the yield could reach $4.7 \mathrm{mmol} \mathrm{H}_{2} \mathrm{gTiO}_{2}^{-1} \mathrm{~h}^{-1}$ through light irradiation for $180 \mathrm{~min}$. Compared with the similar catalyst prepared with industrial alumina, the new catalyst has higher photocatalytic activity. Martín-Gómez et al. [74] carried out the photo reforming experiment on glycerol for hydrogen production after physical mixing of $\mathrm{CuO}$ and $\mathrm{TiO}_{2}$. The results showed that $88 \mathrm{mmol} \mathrm{g}^{-1}$ hydrogen production products could be obtained after a $5 \mathrm{~h}$ reaction with the catalyst. Charisiou et al. [75] prepared $\mathrm{Al}_{2} \mathrm{O}_{3}, \mathrm{CeO}_{2}-\mathrm{Al}_{2} \mathrm{O}_{3}, \mathrm{MgO}-\mathrm{Al}_{2} \mathrm{O}_{3}$, and $\mathrm{La}_{2} \mathrm{O}_{3}-\mathrm{Al}_{2} \mathrm{O}_{3}$ catalysts using $\mathrm{Al}_{2} \mathrm{O}_{3}$ as support for hydrogen production from steam reforming of glycerol. All the catalysts showed good stability during the reaction, and the glycerol conversion rate reached about 90\%. The hydrogen yield can reach 2.4-2.9 mol $\mathrm{H}_{2} \mathrm{~mol}^{-1}$. In the previous section, we introduced the application of steel slag in the field of photocatalysis and found that the modified steel slag as a photocatalyst has potential, combined with the composition of steel slag. We can determine that the steel slag has a great potential in the field of glycerol photo reforming hydrogen production. Mustapha 
Aissaoui et al. [76] used Fe/Mg-bearing metallurgical waste (UGSO) as raw material for the first time to prepare $\mathrm{CaO}-\mathrm{UGSO} 10 / \mathrm{NiO}$ mixed sorbents-catalyst material, and tested the performance of glycerol adsorption enhanced steam reforming. After 30 min of reaction, hydrogen with $95 \%$ purity was obtained, and the catalyst showed good stability. Therefore, steel slag has certain research potential in the field of hydrogen production from glycerol, both in terms of preparation cost and environmental governance.

According to the above, modified steel slag catalyst has been studied extensively in the field of GC preparation by transesterification reaction, and it shows good catalytic performance. At the same time, although no research has been carried out on the preparation of biodiesel and glycerol for hydrogen production, the above analysis and summary show great potential, providing new guidance for solid waste utilization and synthesis of efficient heterogeneous catalysts. This will increase the additional utilization value of steel slag, reduce solid waste pollution, and further promote the development of renewable energy. In Table 2, we summarize the research of steel slag in the above catalytic fields in the current research stage. The results showed that the modified steel slag as catalyst has the advantages of low cost, environmental friendliness, high catalytic efficiency, and good reusability.

Table 2. Application of modified steel slag as catalysts in five catalytic fields.

\begin{tabular}{|c|c|c|c|}
\hline Catalysis Field & Raw Material & Modification Method & Reference \\
\hline \multirow{3}{*}{ Catalytic pyrolysis } & 1. Steel slag & $\begin{array}{l}\text { 1. Physical modification } \\
\text { 2. High-temperature activation modification }\end{array}$ & [39] \\
\hline & $\begin{array}{l}\text { 1. Pine sawdust } \\
\text { 2. Steel slag }\end{array}$ & $\begin{array}{l}\text { Loaded with } \mathrm{Ni} \text { by wet impregnation and high } \\
\text { temperature calcined }\end{array}$ & {$[40]$} \\
\hline & $\begin{array}{l}\text { 1. Electric arc furnace slag } \\
\text { 2. } \mathrm{H}_{2} \mathrm{SO}_{4} \text { and } \mathrm{NaOH}\end{array}$ & Compound modification & {$[41]$} \\
\hline \multirow{3}{*}{ Organic matter degradation } & $\begin{array}{l}\text { 1. Steel converter slag (SCS) } \\
\text { 2. Methanol and salicylic acid (SAM) }\end{array}$ & $\begin{array}{l}\text { 1. Physical modification } \\
\text { 2. Acid modification }\end{array}$ & [44] \\
\hline & $\begin{array}{l}\text { 1. Steel converter slag (SCS) } \\
\text { 2. Methanol and salicylic acid (SAM) } \\
\text { 3. } \mathrm{Co}\left(\mathrm{NO}_{3}\right)_{2}\end{array}$ & $\begin{array}{l}\text { 1. Physical modification } \\
\text { 2. Acid modification }\end{array}$ & {$[26]$} \\
\hline & $\begin{array}{l}\text { 1. Steel slag } \\
\text { 2. } \mathrm{Cu}\end{array}$ & Compound modification & {$[46]$} \\
\hline \multirow{3}{*}{ Electrocatalysis } & $\begin{array}{l}\text { 1. Steel slag } \\
\text { 2. Clay } \\
\text { 3. Pore }\end{array}$ & $\begin{array}{l}\text { 1. Physical modification } \\
\text { 2. High-temperature activation modification }\end{array}$ & {$[43,51]$} \\
\hline & $\begin{array}{l}\text { 1. Steel slag } \\
\text { 2. Zeolite } \\
\text { 3. Pore-forming }\end{array}$ & Compound modification & {$[32]$} \\
\hline & $\begin{array}{l}\text { 1. Kaolin } \\
\text { 2. Steel slag } \\
\text { 3. } \mathrm{NaHCO}_{3}\end{array}$ & Compound modification & {$[31]$} \\
\hline \multirow{3}{*}{ light catalytic } & $\begin{array}{l}\text { 1. LD slag } \\
\text { 2. } \mathrm{HCl} \\
\text { 3. Dimethylformamide } \\
\text { 4. Terephthalic acid }\end{array}$ & Acid modification & [24] \\
\hline & $\begin{array}{l}\text { 1. Steel slag } \\
\text { 2. Industrial Titanium Liquid } \\
\text { 3. Ammonia and } \mathrm{H}_{2} \mathrm{O}_{2}\end{array}$ & Compound modification & {$[57]$} \\
\hline & $\begin{array}{l}\text { 1. Steel slag } \\
\text { 2. } \mathrm{NaOH}\end{array}$ & Alkali modification & {$[29]$} \\
\hline \multirow[t]{2}{*}{ Transesterification } & $\begin{array}{l}\text { 1. Steel slag } \\
\text { 2. } \mathrm{HCl} 3 . \mathrm{NaOH} \text { and } \mathrm{Na}_{2} \mathrm{CO}_{3}\end{array}$ & $\begin{array}{l}\text { 1. Acid modification } \\
\text { 2. Alkali modification } \\
\text { 3. High-temperature activation modification }\end{array}$ & [62] \\
\hline & $\begin{array}{l}\text { 1. ladle furnace steel slag } \\
\text { 2. } \mathrm{NaOH}\end{array}$ & $\begin{array}{l}\text { 1. Alkali modification } \\
\text { 2. High-temperature activation modification }\end{array}$ & [26] \\
\hline
\end{tabular}




\subsection{Carbon Capture and Storage}

With the massive global burning of fossil fuels, the emission of $\mathrm{CO}_{2}$ has an increasingly serious impact on global warming. At present, the global artificial emission of carbon dioxide is more than 3.2 billion tons, while the total utilization of carbon dioxide is less than 200 million tons per year. Compared with the emissions, the utilization rate is far less than the emissions [77], and $\mathrm{CO}_{2}$ capture and storage technology (CCSU) is considered to be a very promising approach to carbon dioxide emission reduction [78]. Therefore, it is very necessary to strengthen the research on CCSU. It is estimated that 1.4 tons of $\mathrm{CO}_{2}$ will be emitted for each ton of steel produced in steel plants [79]. Steel slag and $\mathrm{CO}_{2}$, as wastes of the steel industry, can be treated by means of "using waste to treat waste", thus achieving economic synergies.

$\mathrm{Ca} / \mathrm{Mg}$-rich phase is used to capture and fix carbon dioxide through mineral carbonation, and carbon dioxide combines with $\mathrm{Ca} / \mathrm{Mg}$ to eventually generate carbonate products [80]. Studies have reported that $70-85 \%$ of $\mathrm{Ca} / \mathrm{Mg}$ is extracted from steel slag or magnesium silicate rock [81]. Therefore, it is very necessary to study the leaching of $\mathrm{Ca} / \mathrm{Mg}$ phase in steel slag. Zhao et al. [82] investigated the leaching rate of chromium element and $\mathrm{Ca} / \mathrm{Mg}$ in stainless steel slag, and they first added $\mathrm{MnO}$ to the slag, and then carried out acid leaching treatment. The results show that the content of $\mathrm{MnO}$ and acid treatment have great effects on the fixation of chromium and the leaching of $\mathrm{Ca} / \mathrm{Mg}$ from stainless steel slag. When the content of $\mathrm{MnO}$ is about $5 \%$, the $\mathrm{pH}$ of acid leaching solution is 2, the leaching time is $120 \mathrm{~min}$, and the temperature is $20^{\circ} \mathrm{C}$, the leaching rates of $\mathrm{Ca}$ and $\mathrm{Mg}$ are about $65 \%$ and $55 \%$, respectively. Frederic J. Doucet [81] took BOF and EAF as research objects and successfully extracted from them calcium and magnesium, respectively.

In addition to extracting carbon sequestration substances from steel slag for $\mathrm{CO}_{2}$ capture and storage, steel slag can also be directly used for $\mathrm{CO}_{2}$ capture and storage after removing impurities by simple modification. Walther-Dario et al. [79] synthesized lithium silicate-based $\mathrm{CO}_{2}$ adsorbents using iron and steel metallurgical waste residue as raw material. Using steel slag as a silicon source, lithium silicate group was synthesized by adding (10-30 wt $\% \mathrm{~K}_{2} \mathrm{CO}_{3}$ ). The eutectic phase is formed between $\mathrm{K}_{2} \mathrm{CO}_{3}$ and $\mathrm{Li}_{2} \mathrm{CO}_{3}$, which promotes the diffusion of $\mathrm{CO}_{2}$ to the adsorption material, thus improving the capture efficiency of $\mathrm{CO}_{2}$. Under the condition of $600{ }^{\circ} \mathrm{C}$, the $\mathrm{CO}_{2}$ capture rate of steel slag adsorption material containing $20 \mathrm{wt} \% \mathrm{~K}_{2} \mathrm{CO}_{3}$ reached the maximum. After 10 cycles, the capture efficiency of $\mathrm{CO}_{2}$ only decreases by $10 \%$, indicating that the lithium silicate base has good stability. $\mathrm{Li}$ et al. [83] enhanced $\mathrm{CO}_{2}$ absorption capacity by adding steel slag to seawater. The results show that $\mathrm{MgO}, \mathrm{CaO}$, and $\mathrm{Fe}_{2} \mathrm{O}_{3}$ in the steel slag can enhance the $\mathrm{CO}_{2}$ collecting capacity of seawater. Moreover, $\mathrm{MgO}$ and $\mathrm{CaO}$ have a strong synergistic effect on $\mathrm{CO}_{2}$ capture by seawater. $\mathrm{Fe}_{2} \mathrm{O}_{3}$ has more significant $\mathrm{CO}_{2}$ capture ability than other steel slag components. Under the optimal conditions, the addition of steel slag can ensure that the $\mathrm{CO}_{2}$ capture rate of seawater can reach $90 \%$. This is feasible both in terms of efficiency and cost, and will provide some coastal steel mills with a more rational method of handling steel slag while reducing $\mathrm{CO}_{2}$ content.

\section{Conclusions}

Through the research and exploration of the application status of steel slag in the fields of catalytic pyrolysis, organic degradation, electrocatalysis, photocatalysis, and transesterification, it is found that steel slag has great potential and advantages in the field of catalysis. Through acid modification, alkali modification, high temperature modification, composite modification, and physical modification, the surface area and pore diameter of steel slag can be increased by acid modification, alkaline modification, high temperature modification, compound modification, and physical modification, and the relative content of active substances can be increased. Through calcination and some composite modification methods, the stability of the active substance in steel slag can be enhanced, and the steel slag catalyst can then be reused many times. Steel slag is modified so that its catalytic performance is more efficient than that of similar types of catalysts, such as 
zeolite and some ceramic catalysts. At the same time, in some catalytic reactions, steel slag will react with certain substances (such as copper and nickel), forming a virtuous cycle, speeding up the catalytic process and improving the catalytic performance. At the same time, through the summary of steel slag in the above catalytic fields, it can be seen that steel slag will participate in the reaction in the catalytic process. It also shows great potential in lipid exchange to produce biodiesel and glycerol to produce hydrogen. At present, it is difficult to obtain the ideal steel slag catalyst by a single modification, as most methods are compound modifications. Therefore, efficiency, cost, and complexity should be considered in the selection of modification methods.

At the same time, we can see that the modified steel slag has a good activity for the degradation of organic matter in some wastewater. In China and all over the world, various factories such as dye factories, textile factories, and printing factories discharge a large amount of wastewater organic pollutants every year, causing serious environmental pollution, so the demand for solid catalyst is very large. Considering the cost and performance, steel slag is expected to be widely used in wastewater treatment field. It not only realizes the purpose of "using waste to treat waste", and achieves energy saving, emission reduction, and pollution reduction, but also relieves the massive accumulation of steel slag and improves the additional utilization value of steel slag. In order to further improve and perfect the study of modified steel slag catalyst preparation, the following prospects are put forward, hoping to provide some references for the research in this field:

(1) At present, catalysts were widely used in various fields. Selecting suitable catalysts with high catalytic performance and low costs had been a research hotspot. Modified steel slag had a good development prospect in the field of catalysis. Through the comparison of several catalytic fields, it can be found that the modified steel slag catalyst shows better catalytic performance in wastewater treatment and organic degradation than other fields. Nowadays, the treatment process of wastewater and sewage is complicated and the cost is high. If steel slag can be widely used in this area, it will greatly reduce the cost of sewage treatment. At the same time, it will provide a new direction for the resource utilization of steel slag;

(2) The modification for steel slag using high concentrations of acid and alkali was easy to lead to leaching of other elements, which increased by-product treatment processes. At the same time, it was necessary to strengthen the analysis, including composition of the catalyzed steel slag, metal precipitates, and the effect on the catalytic reaction so as to prepare an efficient catalyst.

Author Contributions: Conceptualization, Y.-T.W.; Writing-original draft preparation, F.-P.W.; Writing-review and editing, T.-J.L., S.C., D.G., Q.Y., X.-M.W., Y.-T.W., Y.-N.Z., and J.-G.L.; Funding acquisition, Y.-T.W. and Y.-N.Z. All authors have read and agreed to the published version of the manuscript.

Funding: The authors wish to acknowledge the financial support from National Natural Science Foundation of China (No: 52004095 and 51704119) and Natural Science Foundation of Hebei Province (E2017209243) and Department of Education of Hebei Province (BJ2019038).

Institutional Review Board Statement: Not applicable.

Informed Consent Statement: Not applicable.

Data Availability Statement: No new data were created or analyzed in this study. Data sharing is not applicable to this article.

Acknowledgments: The authors give thanks to the anonymous reviewers and all the editors in the process of manuscript revision.

Conflicts of Interest: The authors declare no conflict of interest. 


\section{References}

1. Zhang, X.L.; Chen, J.X.; Jiang, J.J.; Li, J.; Tyagi, R.D.; Surampalli, R.Y. The potential utilization of slag generated from iron- and steelmaking industries: A review. Environ. Geochem. Health 2020, 42, 1321-1334. [CrossRef]

2. Wang, X.B.; Li, X.Y.; Yan, X.; Tu, C.; Yu, Z.G. Environmental risks for application of iron and steel slags in soils in China: A review. Pedosphere 2021, 31, 28-42. [CrossRef]

3. Liao, J.L.; Zhang, Z.H.; Ju, J.T.; Zhao, F.Z. Comparative Analysis of Steel Slag Characteristics and Treatment Process. Adv. Mater. Res. 2014, 2817, 378-384. [CrossRef]

4. Fisher, L.V.; Barron, A.R. The recycling and reuse of steelmaking slags-A review. Resour. Conserv. Recycl. 2019, 146, 244-255. [CrossRef]

5. Huang, Y.; Xu, G.P.; Cheng, H.G.; Wang, J.S.; Wan, Y.F.; Chen, H. An overview of utilization of steel slag. Procedia Environ. Sci. 2012, 16, 791-801.

6. Huo, B.B.; Li, B.L.; Huang, S.Y.; Chen, Y.; Zhang, Y.; Banthia, N. Hydration and soundness properties of phosphoric acid modified steel slag powder. Constr. Build. Mater. 2020, 254, 119319. [CrossRef]

7. Gao, J.T.; Li, S.Q.; Zhang, Y.T.; Zhang, Y.L.; Chen, P.Y.; Shen, P. Process of Re-Resourcing of Converter Slag. J. Iron Steel Res. 2011, 18, 32-39. [CrossRef]

8. Yuan, H.Z.; Dan, Z.K.; Wang, Q.Q.; He, S.P. Contact angle and adhesion of $\mathrm{CaO}-\mathrm{SiO}_{2}$-and $\mathrm{CaO}-\mathrm{Al}_{2} \mathrm{O}_{3}$-based mold slags on solid steel of various compositions. J. Mater. Res. Technol. 2020, 9, 7828-7837. [CrossRef]

9. Lun, Y.; Zhou, M.; Cai, X.; Xu, F. Methods for improving volume stability of steel slag as fine aggregate. J. Wuhan Univ. Technol. Mater. Sci. Ed. 2008, 23, 737-742. [CrossRef]

10. Wu, W.; Meng, H.D.; Liu, L. Melting Characteristics of recycling slag in decarburization converter and its application effects. J. Iron Steel Res. 2013, 20, 7-12. [CrossRef]

11. Liu, J.; Yu, B.; Wang, Q. Application of steel slag in cement treated aggregate base course. J. Clean. Prod. 2020, $269,121733$. [CrossRef]

12. Shih, P.H.; Wu, Z.Z.; Chiang, H.L. Characteristics of bricks made from waste steel slag. Waste Manag. 2004, $24,1043-1047$. [CrossRef] [PubMed]

13. Venkatesan, B.; Lijina, V.J.; Kannan, V.; Dhevasenaa, P.R. Partial replacement of fine aggregate by steel slag and coarse aggregate by walnut shell in concrete. Mater. Today 2020, 37, 1761-1766. [CrossRef]

14. Jiao, W.X.; Sha, A.M.; Liu, Z.Z.; Li, W.; Jiang, W.; Qin, W.; Hu, Y.J. Study on thermal properties of steel slag asphalt concrete for snow-melting pavement. J. Clean. Prod. 2020, 277, 123574. [CrossRef]

15. Xian, W.A.; Qing-Sheng, C.A. Steel Slag as an Iron Fertilizer for Corn Growth and Soil Improvement in a Pot Experiment. Pedosphere 2006, 16, 519-524.

16. Diao, J.; Zhou, W.; Ke, Z.Q.; Qiao, Y.; Zhang, T.; Liu, X.; Xie, B. System assessment of recycling of steel slag in converter steelmaking. J. Clean. Prod. 2016, 125, 159-167. [CrossRef]

17. Lundkvist, K.; Brämming, M.; Larsson, M.; Samuelsson, C. System analysis of slag utilization from vanadium recovery in an integrated steel plant. J. Clean. Prod. 2013, 47, 43-51. [CrossRef]

18. Altun, I.A.; Yilmaz, I. Study on steel furnace slags with high MgO as additive in Portland cement. Cem. Concr. Res. 2002, 32, 1247-1249. [CrossRef]

19. Wang, G.; Wang, Y.H.; Gao, Z.L. Use of steel slag as a granular material: Volume expansion prediction and usability criteria. J. Hazard. Mater. 2010, 184, 555-560. [CrossRef]

20. Lee, D.J.; Jeong, K.H.; Lee, D.H.; Lee, S.H.; Jung, M.W.; Jang, Y.N.; Jo, G.G.; Kwag, J.H.; Yi, H.K.; Park, Y.K.; et al. Kwon Catalytic pyrolysis of swine manure using $\mathrm{CO}_{2}$ and steel slag. Environ. Int. 2019, 133, 105204. [CrossRef]

21. Matthaiou, V.; Oulego, P.; Frontistis, Z.; Collado, S.; Hela, D.; Konstantinou, I.K.; Diaz, M.; Mantzavinos, D. Valorization of steel slag towards a Fenton-like catalyst for the degradation of paraben by activated persulfate. Chem. Eng. J. 2019, 360, 728-739. [CrossRef]

22. Ekaterina, K.; Narendra, K.; Taina, O.; Juha, L.; Christian, L.; Marcus, P.; Janne, P.; Jarno, S.; Yu, M.D. Transformation of industrial steel slag with different structure-modifying agents for synthesis of catalysts. Catal. Today 2020, 355, 768-780.

23. Wang, S.N.; Yao, S.J.; Du, K.; Yuan, R.F.; Chen, H.L.; Wang, F.; Zhou, B.H. The mechanisms of conventional pollutants adsorption by modified granular steel slag. Environ. Eng. Res. 2021, 26, 86-98.

24. Sarkar, C.; Basu, J.K.; Samanta, A.N. Synthesis of MIL-53(Fe)/ $/ \mathrm{SiO}_{2}$ composite from LD slag as a novel photo-catalyst for methylene blue degradation. Chem. Eng. J. 2019, 377, 119621. [CrossRef]

25. Kholkina, E.; Kumar, N.; Ohra-aho, T.; Lehtonen, J.; Lindfors, C.; Perula, M.; Peltonen, J.; Salonen, J.; Murzin, D.Y. Synthesis and Characterization of Novel Catalytic Materials Using Industrial Slag: Influence of Alkaline Pretreatment, Synthesis Time and Temperature. Top. Catal. 2019, 62, 738-751. [CrossRef]

26. Cheng, M.; Zeng, G.M.; Huang, D.L.; Lai, C.; Liu, Y.; Zhang, C.; Wan, J.; Hu, L.; Zhou, C.Y.; Xiong, W.P. Efficient degradation of sulfamethazine in simulated and real wastewater at slightly basic $\mathrm{pH}$ values using Co-SAM-SCS $/ \mathrm{H}_{2} \mathrm{O}_{2}$ Fenton-like system. Water Res. 2018, 138, 7-18. [CrossRef] [PubMed]

27. Sugano, Y.; Sahara, R.; Murakami, T.; Narushima, T.; Iguchi, Y.; Ouchi, C. Hydrothermal synthesis of zeolite A using blast furnace slag. ISIJ Int. 2005, 45, 937-945. [CrossRef] 
28. Okoye, P.U.; Abdullah, A.Z.; Hameed, B.H. Stabilized ladle furnace steel slag for glycerol carbonate synthesis via glycerol transesterification reaction with dimethyl carbonate. Energy Convers. Manag. 2017, 133, 477-485. [CrossRef]

29. Zhang, Y.J.; Li Cai Liu, L.C.; Xu, Y.; Wang, Y.C.; Xu, D.L. A new alkali-activated steel slag-based cementitious material for photocatalytic degradation of organic pollutant from waste water. J. Hazard. Mater. 2012, 209-210, 146-150. [CrossRef]

30. Cao, L.; Shen, W.; Huang, J.Q.; Yang, Y.; Zhang, D.; Huang, X.Q.; Lv, Z.J.; Ji, X.L. Process to utilize crushed steel slag in cement industry directly: Multi-phased clinker sintering technology. J. Clean. Prod. 2019, 217, 520-529. [CrossRef]

31. Wang, Z.Y.; Song, B.; Li, J.F.; Teng, X.L. Degradation of norfloxacin wastewater using kaolin/steel slag particle electrodes: Performance, mechanism and pathway. Chemosphere 2020, 270, 128652. [CrossRef]

32. Zhang, Z.J.; Feng, Y.; Liu, N.; Zhao, Y.H.; Wang, X.W.; Yang, S.M.; Yingying Long, Y.Y.; Qiu, L.P. Preparation of Sn/Mn loaded steel slag zeolite particle electrode and its removal effect on rhodamine B(RhB). J. Water Process Eng. 2020, 37, 101417. [CrossRef]

33. Lian, F.; Ma, L.J.; Chou, K. Industrial research on the high-temperature modification of Basic Oxygen Furnace slag with solid waste compound. J. Clean. Prod. 2017, 143, 549-556. [CrossRef]

34. Zhang, K.; Pei, Z.; Wang, D. Organic solvent pretreatment of lignocellulosic biomass for biofuels and biochemicals: A review. Bioresour. Technol. 2016, 199, 21-33. [CrossRef] [PubMed]

35. Zhang, X.; Sun, L.; Chen, K.; Xie, X.; Zhao, B.; Si, H.; Meng, G. Comparison of catalytic upgrading of biomass fast pyrolysis vapors over $\mathrm{CaO}$ and $\mathrm{Fe}$ (III)/CaO catalysts. J. Anal. Appl. Pyrolysis 2014, 108, 35-40. [CrossRef]

36. Lin, X.N.; Zhang, Z.F.; Zhang, Z.J.; Sun, J.P.; Wang, Q.W.; Pittman, C.U. Catalytic fast pyrolysis of a wood-plastic composite with metal oxides as catalysts. J. Waste Manag. 2018, 79, 38-47. [CrossRef] [PubMed]

37. Stefanidis, S.D.; Kalogiannis, K.G.; Iliopoulou, E.F.; Lappas, A.A.; Pilavachi, P.A. In-situ upgrading of biomass pyrolysis vapors: Catalyst screening on a fifixed bed reactor. Bioresour. Technol. 2011, 102, 8261-8267. [CrossRef] [PubMed]

38. Chen, X.; Chen, Y.Q.; Yang, H.P.; Wang, X.H.; Che, Q.F.; Wei Chen Chen, H.P. Catalytic fast pyrolysis of biomass: Selective deoxygenation to balance the quality and yield of bio-oil. Bioresour. Technol. 2019, 273, 153-158. [CrossRef] [PubMed]

39. Guo, F.Q.; Liang, S.; Zhao, X.M.; Jia, X.P.; Peng, K.Y.; Jiang, X.C.; Qian, L. Catalytic reforming of biomass pyrolysis tar using the low-cost steel slag as catalyst. Energy 2019, 189, 116161. [CrossRef]

40. Guo, F.Q.; Zhao, X.M.; Peng, K.Y.; Liang, S.; Jia, X.P.; Lin Qian, L. Catalytic reforming of biomass primary tar from pyrolysis over waste steel slag based catalysts. Int. J. Hydrogen Energy 2019, 44, 16224-16233. [CrossRef]

41. Kabir, G.; Mohd Din, A.T.; Hameed, B.H. Pyrolysis of oil palm mesocarp fiber catalyzed with steel slag-derived zeolite for bio-oil production. Bioresour. Technol. 2018, 249, 42-48. [CrossRef]

42. Wang, Z.Y.; Qi, J.Y.; Feng, Y.; Li, K.; Li, X. Preparation of catalytic particle electrodes from steel slag and its performance in a three-dimensional electrochemical oxidation system. J. Ind. Eng. Chem. 2014, 20, 3672-3677. [CrossRef]

43. Wang, Z.Y.; He, X.L.; Li, J.F.; Qi, J.Y.; Zhao, C.; Yang, G. Preparation of magnetic steel-slag particle electrode and its performance in a novel electrochemical reactor for oilfield wastewater advanced treatment. J. Ind. Eng. Chem. 2018, 58, 18-23. [CrossRef]

44. Cheng, M.; Zeng, G.M.; Huang, D.L.; Lai, C.; Liu, Y.; Xu, P.; Zhang, C.; Wan, J.; Hu, L.; Xiong, W.P.; et al. Salicylic acid-methanol modified steel converter slag as heterogeneous Fenton-like catalyst for enhanced degradation of alachlor. Chem. Eng. J. 2017, 327, 686-693. [CrossRef]

45. Shen, W.G.; Zhou, M.K.; Ma, W.; Hu, J.Q.; Cai, Z. Investigation on the application of steel slag-fly ash-phosphogypsum solidified material as road base material. J. Hazard. Mater. 2009, 164, 99-104. [CrossRef]

46. Yoon, S.; Bae, S. Development of magnetically separable Cu catalyst supported by pre-treated steel slag. Korean J. Chem. Eng. 2019, 36, 1814-1825. [CrossRef]

47. Jaehyeong, P.; Sungjun, B. Formation of Fe nanoparticles on water-washed coal fly ash for enhanced reduction of p-nitrophenol. Chemosphere 2018, 202, 733-741.

48. Wei, J.Z.; Feng, Y.J.; Sun, X.J.; Liu, J.F.; Zhu, L.M. Effectiveness and pathways of electrochemical degradation of pretilachlor herbicides. J. Hazard. Mater. 2011, 189, 84-91. [CrossRef]

49. Shi, C.J.; Qian, J.S. High performance cementing materials from industrial slags-A review, Resources. Conserv. Recycl. 2000, 29, 195-207. [CrossRef]

50. Yuan, M.; Yan, F.R.; Chen, Y.G.; Luo, J.J.; Li, Z.Y. A three-dimensional electrochemical oxidation system with alpha-Fe $2 \mathrm{O}_{3} / \mathrm{PAC}$ as the particle electrode for ammonium nitrogen wastewater treatment. Resources. Conserv. Recycl. 2020, 29, $195-207$.

51. Wang, Z.Y.; Qi, J.Y.; Feng, Y.; Li, K.; Li, X. Fabrication and electrocatalytic performance of a novel particle electrode. J. Catal. Commun. 2014, 46, 165-168. [CrossRef]

52. Zhang, B.G.; Hou, Y.P.; Yu, Z.B.; Liu, Y.X.; Huang, J.; Qian, L.; Xiong, J.H. Three-dimensional electro-Fenton degradation of Rhodamine B with efficient Fe-Cu/kaolin particle electrodes: Electrode's optimization, kinetics, influencing factors and mechanism. Sep. Purif. Technol. 2019, 210, 60-68. [CrossRef]

53. Ramezani, H.; Naser, S.; Reza, S. NaY zeolite as a platform for preparation of Ag nanoparticles arrays in order to construction of $\mathrm{H}_{2} \mathrm{O}_{2}$ sensor. Sens. Actuators B Chem. 2017, 248, 571-579. [CrossRef]

54. Kuang, P.J.; Chen, N.; Feng, C.F.; Li, M.; Dong, S.S.; Lv, L.; Zhang, J.; Hu, Z.X.; Deng, Y. Construction and optimization of an iron particle-zeolite packing electrochemical-adsorption system for the simultaneous removal of nitrate and by-products. J. Taiwan Inst. Chem. Eng. 2018, 86, 101-112. [CrossRef]

55. Rożek, P.; Król, M.; Mozgawa, W. Geopolymer-zeolite composites: A review. J. Clean. Prod. 2019, 230, 557-579. [CrossRef] 
56. Yang, Z.; Xu, X.; Liang, X.; Lei, C.; Wei, Y.; He, P.; Lv, B.; Ma, H.; Lei, Z. MIL-53(Fe)-graphene nanocomposites: Efficient visible-light photocatalysts for the selective oxidation of alcohols. Appl. Catal. B Environ. 2016, 198, 112-123. [CrossRef]

57. Chen, X.E.; Cui, X.M.; Huang, X.M.; Huang, Z.C. Photocatalytic degradation of phenol with steel slag supported TiO 2 . New Chem. Mater. 2014, 42, 162-163+172.

58. Shao, N.N.; Li, S.; Yan, F.; Su, Y.P.; Liu, F.; Zhang, Z.T. An all-in-one strategy for the adsorption of heavy metal ions and photodegradation of organic pollutants using steel slag-derived calcium silicate hydrate. J. Hazard. Mater. 2020, 382, 121120. [CrossRef] [PubMed]

59. Da Silva, G.P.; Mack, M.; Contiero, J. Glycerol: A promising and abundant carbon source for industrial microbiology. Biotechnol. Adv. 2008, 27, 30-39. [CrossRef]

60. Okoye, P.U.; Hameed, B.H. Review on recent progress in catalytic carboxylation and acetylation of glycerol as a byproduct of biodiesel production. Renew. Sustain. Energy Rev. 2016, 74, 387-401. [CrossRef]

61. Datta, A.; Mandal, B.K. A comprehensive review of biodiesel as an alternative fuel for compression ignition engine. Renew. Sustain. Energy Rev. 2016, 57, 799-821. [CrossRef]

62. Xie, W.L.; Zhao, L.L. Production of biodiesel by transesterification of soybean oil using calcium supported tin oxides as heterogeneous catalysts. Energy Convers. Manag. 2013, 76, 55-62. [CrossRef]

63. Tang, S.; Wang, L.; Yi, Z.; Li, S.; Tian, S.; Wang, B. Study on preparation of $\mathrm{Ca} / \mathrm{Al} / \mathrm{Fe}_{3} \mathrm{O}_{4}$ magnetic composite solid catalyst and its application in biodiesel transesterification. Fuel Process. Technol. 2012, 95, 84-89. [CrossRef]

64. Ezzah-Mahmudah, S.; Lokman, I.M.; Saiman, M.I.; Yun, T.Y. Synthesis and characterization of $\mathrm{Fe}_{2} \mathrm{O}_{3} / \mathrm{CaO}$ derived from Anadara Granosa for methyl ester production. Energy Convers. Manag. 2016, 126, 124-131. [CrossRef]

65. Saba, T.; Estephane, J.; Khoury, B.E.; Khoury, M.E.; Khazma, M.; Zakhem, H.E.; Aouad, S. Biodiesel production from refined sunflower vegetable oil over KOH/ZSM5 catalysts. Renew. Energy 2016, 90, 301-306. [CrossRef]

66. Zhu, Z.Y.; Liu, Y.B.; Cong, W.J.; Zhao, X.B.; Jidon, J.; Wei, T.; Fang, Z. Soybean biodiesel production using synergistic CaO/Ag nano catalyst: Process optimization, kinetic study, and economic evaluation. Ind. Crop. Prod. 2021, 166, 113479. [CrossRef]

67. Li, H.; Liu, F.S.; Ma, X.L.; Cui, P.; Guo, M.; Li, Y.; Gao, Y.; Zhou, S.J.; Yu, M.Z. An efficient basic heterogeneous catalyst synthesis of magnetic mesoporous Fe@C support SrO for transesterification. Renew. Energy 2020, 149, 816-827. [CrossRef]

68. Xie, W.; Wang, H. Immobilized polymeric sulfonated ionic liquid on core-shell structured $\mathrm{Fe}_{3} \mathrm{O}_{4} / \mathrm{SiO}_{2}$ composites: A magnetically recyclable catalyst for simultaneous transesterification and esterification of low-cost oils to biodiesel. Renew. Energy 2020, 145, 1709-1719. [CrossRef]

69. Zheng, L.P.; Xia, S.Z.; Hou, Z.T.; Zhang, M.Y.; Hou, Z.Y. Transesterification of glycerol with dimethyl carbonate over Mg-Al hydrotalcites. Chin. J. Catal. 2014, 35, 310-318. [CrossRef]

70. Zheng, L.P.; Xia, S.X.; Lu, X.Y.; Hou, Z.Y. Transesterification of glycerol with dimethyl carbonate over calcined Ca-Al hydrocalumite. Chin. J. Catal. 2015, 36, 1759-1765. [CrossRef]

71. Simanjuntak, F.S.H.; Kim, T.K.; Lee, S.D.; Ahn, B.S.; Kim, H.S.; Lee, H. CaO-catalyzed synthesis of glycerol carbonate from glycerol and dimethyl carbonate: Isolation and characterization of an active Ca species. Appl. Catal. A Gen. 2011, 401, 220-225. [CrossRef]

72. Liu, G.H.; Yang, J.Y.; Xu, X.R. Synthesis of hydrotalcite-type mixed oxide catalysts from waste steel slag for transesterification of glycerol and dimethyl carbonate. Sci. Rep. 2020, 10, 1063-1071. [CrossRef] [PubMed]

73. Osman, A.I.; Skillen, N.C.; Robertson, P.K.J.; Rooney, D.W.; Morgan, K.e.v.i.n. Exploring the photocatalytic hydrogen production potential of titania doped with alumina derived from foil waste. Int. J. Hydrogen Energy 2020, 45, 34494-34502. [CrossRef]

74. Martín-Gómez, J.; Hidalgo-Carrillo, J.; Montes, V.; Estévez-Toledano, R.C.; Escamilla, J.C.; Marinas, A.; Urbano, F.J. EPR and CV studies cast further light on the origin of the enhanced hydrogen production through glycerol photoreforming on $\mathrm{CuO}^{\mathrm{TiO}} \mathrm{O}_{2}$ physical mixtures. J. Environ. Chem. Eng. 2021, 9, 105336. [CrossRef]

75. Charisiou, N.D.; Italiano, C.; Pino, L.; Sebastian, V.S.; Vita, A.; Goula, M.A. Hydrogen production via steam reforming of glycerol over $\mathrm{Rh} / \gamma-\mathrm{Al}_{2} \mathrm{O}_{3}$ catalysts modified with $\mathrm{CeO}_{2}, \mathrm{MgO}$ or $\mathrm{La}_{2} \mathrm{O}_{3}$. Renew. Energy 2020, 162, 908-925. [CrossRef]

76. Aissaoui, M.; Sahraei, O.A.Z.; Yancheshmeh, M.S.; Iliut, M.C. Development of a Fe/Mg-bearing metallurgical waste stabilized$\mathrm{CaO} / \mathrm{NiO}$ hybrid sorbent-catalyst for high purity $\mathrm{H}_{2}$ production through sorption-enhanced glycerol steam reforming. Int. J. Hydrogen Energy 2020, 45, 18452-18465. [CrossRef]

77. Osman, A.I.; Hefny, M.; Abdel Maksoud, M.I.A.; Elgarahy, A.M.; Rooney, D.W. Recent advances in carbon capture storage and utilization technologies: A review. Environ. Chem. Lett. 2020, 19, 797-849. [CrossRef]

78. Theo, W.L.; Lim, J.S.; Hashim, H.; Mustaffa, A.A.; Ho, W.S. Review of pre-combustion capture and ionic liquid in carbon capture and storage. Appl. Energy 2016, 183, 1633-1663. [CrossRef]

79. Walther-Darío, B.P.; Brenda, A.V.; Rosa-María, R.Z. Synthesis and evaluation in the $\mathrm{CO}_{2}$ capture process of potassium-modified lithium silicates produced from steel metallurgical slags. Mater. Res. Bull. 2021, 141, 111353.

80. Leung, D.Y.C.; Caramanna, G.; Maroto-Valer, M.M. An overview of current status of carbon dioxide capture and storage technologies. Renew. Sustain. Energy Rev. 2014, 39, 426-443. [CrossRef]

81. Doucet, F.J. Effective $\mathrm{CO}_{2}$-specific sequestration capacity of steel slags and variability in their leaching behavior in view of industrial mineral carbonation. Miner. Eng. 2009, 23, 262-269. [CrossRef] 
82. Zhao, Q.; Liu, K.; Sun, L.F.; Liu, C.J.; Jiang, M.; Saxén, H.; Zevenhoven, R. Towards carbon sequestration using stainless steel slag via phase modification and co-extraction of calcium and magnesium. Process Saf. Environ. Prot. 2020, 133, 73-81. [CrossRef]

83. Li, H.W.; Tang, Z.G.; Li, N.; Cui, L.P.; Mao, X.Z. Mechanism and process study on steel slag enhancement for $\mathrm{CO}_{2}$ capture by seawater. Appl. Energy 2020, 276, 115515. [CrossRef] 